\title{
Penyuluhan Tentang Malaria \\ Pada Keluarga Penerima Manfaat Program Keluarga Harapan (KPM-PKH) Kecamatan Woyla, Kabupaten Aceh Barat
}

\author{
Arif Iskandar1, Azwar' ${ }^{2}$, Ishalyadi ${ }^{3}$ \\ 1,2,3Jurusan Ilmu Kesehatan Masyarakat, Universitas Teuku Umar \\ Email: arifiskandar@utu.ac.id \\ Email: azwar@utu.ac.id \\ Email: ishalyadi@utu.ac.id
}

Submitted: 24 Juni 2020 Revised: 29 Juni $2020 \quad$ Accepted: 30 Juli 2020

\begin{abstract}
Malaria is one of the endemic diseases that are often found in the tropics. This disease is caused by the plasmodium parasite and is transmitted by female Anopheles mosquitoes. The World Health Organization (WHO) estimates that around 300-500 million cases are reported each year with one million deaths occurring in developing countries. Efforts to eradicate malaria will be carried out by involving community participation through eradicating malaria-causing vectors. In this regard, it is necessary to have public awareness to practice clean living by maintaining environmental cleanliness as a form of malaria prevention efforts. The counseling was carried out aimed at increasing public knowledge about malaria and prevention efforts. The counseling method is carried out with lectures and face-to-face discussions with participants. The results of this counseling can foster public awareness, attitudes, and behavior towards malaria prevention and control. The community is expected to be able to increase awareness of malaria transmission through prevention efforts undertaken.
\end{abstract}

Keywords: Malaria, prevention, community

\begin{abstract}
Abstrak
Penyakit malaria menjadi salah satu penyakit endemis yang sering dijumpai di wilayah tropis. Penyakit ini disebabkan oleh parasit plasmodium dan ditularkan oleh nyamuk Anopheles betina. Organisasi Kesehatan Dunia (WHO) memperkirakan sekitar 300-500 juta kasus dilaporkan setiap tahun dengan satu juta kematian terjadi di negara-negara berkembang. Upaya pemberantasan malaria akan dapat dilakukan dengan melibatkan peran serta masyarakat melalui pemberantasan vektor penyebab malaria. Berkenaan dengan hal tersebut, perlu adanya kesadaran masyarakat untuk menjalankan perilaku hidup bersih dengan menjaga kebersihan lingkungan sebagai salah satu bentuk upaya pencegahan malaria. Penyuluhan ini dilaksanakan bertujuan untuk meningkatkan pengetahuan masyarakat tentang malaria dan upaya pencegahannya. Metode penyuluhan dilaksanakan dengan ceramah dan diskusi secara tatap muka dengan peserta. Hasil dari penyuluhan ini dapat menumbuhkan kesadaran, sikap, dan perilaku masyarakat terhadap pencegahan dan pengendalian malaria. Masyarakat diharapkan mampu meningkatkan kewaspadaan terhadap penularan malaria melalui upaya pencegahan yang dilakukan.
\end{abstract}

Kata Kunci: Malaria, pencegahan, masyarakat

\section{PENDAHULUAN}

Penyakit malaria termasuk salah satu penyakit communicable disease yang bisa menimbulkan kematian di beberapa negara berkembang yang beriklim tropis. Penyakit infeksi ini disebabkan oleh parasit jenis plasmodium dan ditularkan melalui 
perantara nyamuk Anopheles betina. World Health Organization (WHO) menyatakan $40 \%$ jumlah penduduk dunia berada pada wilayah endemis malaria (WHO, 2000).

Penyebaran malaria di dunia dilaporkan sebagian besar berada di benua Afrika (88\%), wilayah Asia Tenggara (10\%), dan wilayah Mediterania Timur (2\%). WHO memperkirakan kasus malaria yang dilaporkan dalam setiap tahunnya sekitar 300-500 juta kasus dengan satu juta kematian terjadi pada negara-negara berkembang. Meskipun World Malaria Report 2015 melaporkan risiko penularan malaria menurun sebesar $37 \%$ dan risiko kematian menurun sebesar 60\% antara tahun 2000 dan 2015 (Chan, 2015).

Kejadian Luar Biasa (KLB) malaria tidak hanya mengakibatkan gangguan kesehatan bagi masyarakat, namun juga dapat menurunkan produktivitas dan terganggunya kestabilan ekonomi masyarakat. KLB malaria juga dapat menimbulkan dampak pada sektor pariwisata akibat dari malaria impor. Malaria impor merupakan kasus malaria yang terjadi pada orang yang berisiko mengalami penularan disaat berkunjung ke daerah endemis malaria dan kembali ke daerah asalnya yang bukan daerah endemis (Winardi, 2004). Kematian dan morbiditas yang tinggi akibat malaria berkaitan dengan keadaan ekonomi pada negara-negara berkembang. Kasus malaria tinggi pada beberapa negara atau wilayah miskin dan memiliki sanitasi yang buruk (Amegah, et al., 2013).

Indonesia merupakan salah satu daerah endemis malaria dan 50\% penduduknya berada pada wilayah endemis malaria. Pada tahun 2015, prevalensi kejadian malaria di Indonesia adalah 1,4\% dengan angka insiden yaitu $0,3 \%$ dan Annual Parasite Incidence (API) yaitu 0,85\% (Triana, et al., 2017).

Berdasarkan hasil Riset Kesehatan Dasar, prevalensi malaria di Aceh mengalami penurunan yaitu dari 9,3\% pada tahun 2013 menjadi $0,20 \%$ pada tahun 2018 (Riskesdas 2013; Riskesdas, 2018). Beberapa daerah yang termasuk wilayah endemis malaria di Aceh diantaranya, Sabang, Simeuleu, Pulau Aceh, Pulau Banyak, Beutong Ateuh, Padang Tiji, Lampanah, serta Woyla (Dinas Kesehatan Provinsi Aceh, 2010).

Seseorang yang berada di wilayah endemis malaria berisiko terhadap penularan malaria. Begitu juga orang yang bepergian ke daerah endemis berisiko tinggi tertular malaria. Penyakit malaria bisa menyerang siapa saja, namun yang memiliki risiko paling besar adalah bagi kalangan ibu hamil, anak-anak, serta orang-orang yang tidak memiliki imunitas tubuh yang kuat. Pada beberapa kasus, ibu hamil yang telah terinfeksi malaria 
dapat berisiko menularkan ke bayinya sebelum kelahiran atau selama persalinan (Agomo \& Oyibo, 2013).

Pengendalian malaria akan dapat dilakukan dengan melibatkan peran serta masyarakat. Adapun upaya yang harus dilakukan masyarakat yaitu dengan menjaga kebersihan lingkungan dan pemukiman, sehingga dapat mengurangi dan menghilangkan tempat perkembangbiakan nyamuk sebagai sumber penularan. Hal ini tentu saja tidaklah mudah, karena salah satu aspek menyangkut pada perubahan sikap dan perilaku masyarakat itu sendiri. Pengabdian masyarakat ini dilakukan dengan tujuan untuk meningkatkan pengetahuan masyarakat terhadap penyakit malaria beserta pencegahannya.

\section{METODE PELAKSANAAN}

Kegiatan ini dilaksanakan dalam bentuk penyuluhan kesehatan yang disampaikan kepada Keluarga Penerima Manfaat Program Keluarga Harapan (KPM-PKH) Gampong Rantau Panyang Kecamatan Woyla Kabupaten Aceh Barat. Penyampaian materi dilakukan dengan metode ceramah dan diskusi, serta menampilkan power point melalui laptop dan LCD.

Secara teknis pelaksanaan kegiatan dilakukan dengan mengumpulkan peserta di balai desa. Peserta yang hadir diberikan penjelasan terkait penyebab malaria, cara penularan malaria, gejala malaria serta bagaimana upaya pencegahan dan pengendalian malaria. Kegiatan ini dilaksanakan selama sehari pada tanggal 18 Januari 2020 di Gampong Rantau Panyang Kecamatan Woyla Kabupaten Aceh Barat.

\section{HASIL DAN PEMBAHASAN}

Penyuluhan merupakan suatu proses yang dilakukan dalam memberikan informasi untuk mendorong perubahan sikap dan perilaku individu, kelompok, dan masyarakat dengan tujuan dapat menambah pengetahuan bagi masyarakat, serta mampu menyelesaikan permasalahan yang dihadapi (Amanah, 2017).

Kegiatan penyuluhan yang dilaksanakan di Gampong Rantau Panyang Kecamatan Woyla Kabupaten Aceh Barat merupakan salah satu program pengabdian masyarakat. Adapun tahapan yang dilakukan diawali dengan penyampaian materi tentang penyebab malaria, cara penularan malaria, gejala malaria, vektor malaria, upaya pencegahan dan pengendalian vektor malaria.

Pengetahuan tentang malaria perlu diketahui oleh masyarakat dikarenakan penyakit ini termasuk dalam salah satu jenis penyakit menular dan mudah terjadi penularannya pada manusia. Penularan malaria sangat dipengaruhi oleh keadaan 
lingkungan yang dijadikan sebagai tempat perkembangbiakan vektor.

Malaria adalah penyakit infeksi endemik yang ditularkan melalui vektor dan penyebabnya adalah protozoa parasit dari genus plasmodium. Ada beberapa spesies plasmodium yang menjadi penyebab malaria pada manusia, yaitu plasmodium malariae, plasmodium vivax, plasmodium falciparum, plasmodium ovale, dan plasmodium knowlesi. Parasit ini ditularkan ke manusia melalui nyamuk Anopheles betina yang membutuhkan iklim suhu tinggi untuk berkembang. Malaria pada umumnya ditemukan di daerah-daerah yang lebih hangat di dunia yang lebih dekat dengan garis khatulistiwa, termasuk negara tropis dan subtropis. Parasit malaria yang berkembang dalam tubuh nyamuk juga membutuhkan lingkungan yang hangat untuk menyelesaikan proses siklus perkembangbiakannya sebelum mencapai tahap penularan ke manusia (Suwonkerd, et al., 2013).

Gejala malaria akan muncul setelah adanya gigitan nyamuk sebagai pembawa parasit plasmodium. Berdasarkan manifestasi klinisnya, gejala malaria dapat dikelompokkan menjadi 2 jenis, yaitu gejala malaria ringan dan gejala malaria berat. Gejala malaria ringan ditandai dengan adanya demam, mual-mual, muntah, diare, menggigil disertai sakit kepala, dan nyeri otot (Harijanto, 2000;
Purwaningsih, 2000). Sedangkan gejala malaria berat ditandai dengan adanya gangguan kesadaran, kondisi tubuh terasa sangat lemas, kejang-kejang, perdarahan pada hidung, gusi dan saluran pencernaan berdarah, sesak nafas, suhu tubuh tinggi, mata atau hidung kuning, muntah-muntah, serta anemia (Purwaningsih, 2000; Harijanto, et al., 2000).

Gejala malaria ringan memiliki 3 stadium, yaitu stadium dingin, stadium demam, dan stadium berkeringat. Pada stadium dingin tubuh penderita merasakan kedinginan dan menggigil, kulit kering, bibir dan jari kebiruan, denyut nadi kencang, serta muntah. Gejala ini berlangsung selama 15 menit sampai 1 jam. Stadium demam ditandai dengan keadaan penderita badan panas dengan suhu mencapai $40^{\circ} \mathrm{C}$ atau lebih, kulit kering, muka pucat dan merah, sakit kepala, bahkan kejang-kejang. Gejala tersebut berlangsung selama 2 jam sampai 4 jam. Pada stadium berkeringat, penderita selalu mengeluarkan keringat, sehingga penderita sering kehausan dan kondisi tubuh lemah, suhu tubuh di bawah rata-rata dan menyebabkan suhu tubuh menjadi dingin (Harijanto, 2000).

Penyampaian materi terkait upaya pencegahan malaria yaitu dengan cara meningkatkan kewaspadaan terhadap risiko penularan malaria. Pencegahan 
yang dapat dilakukan dengan menghindari dari gigitan nyamuk melalui penyemprotan insektisida, penggunaan repellent, tidur menggunakan kelambu, pemasangan kawat kasa pada ventilasi rumah, serta dengan menjaga kebersihan diri dan lingkungan. Apabila berkunjung ke daerah-daerah endemis malaria, maka minumlah obat anti malaria Klorokuin. Obat jenis ini berfungsi untuk mencegah masuknya parasit plasmodium ke dalam tubuh.

Untuk pengendalian malaria, masyarakat juga dianjurkan membudidayakan jenis tanaman pengusir nyamuk pada pekarangan rumah, seperti lavender, serai, zodia, rosemary, dan geranium. Tanaman-tanaman ini terbukti mengandung zat aktif yang tidak disukai serangga. Contohnya tanaman serai (Andropogon nardus L.) mengandung zat aktif sitronelol dan geraniol yang tidak disukai serangga, dan tanaman zodiac (Evodia Suaveolens) mengandung senyawa linalool yang berfungsi sebagai pengusir nyamuk (Budiasih, 2011).

Pada penyuluhan ini juga disampaikan perlu adanya keterlibatan masyarakat terhadap upaya-upaya pencegahan malaria. Saat ini pemerintah Kabupaten Aceh Barat telah menerima penghargaan sertifikasi eliminasi malaria dari Kementerian Kesehatan Republik Indonesia. Hal ini menandakan bahwa Kabupaten Aceh Barat telah dianggap terbebas dari malaria.

\section{PENUTUP}

Penyuluhan kesehatan sebagai salah satu program pengabdian masyarakat penting dilakukan untuk memberikan informasi kepada masyarakat. Kegiatan ini diharapkan dapat menambah pemahaman masyarakat tentang malaria, sehingga mampu meningkatkan kewaspadaan dini terhadap penularan malaria melalui upaya pencegahan yang dilakukan.

Saran kepada aparatur gampong agar dapat berkomitmen mengerakkan masyarakat untuk melaksanakan kegiatan rutin gotong royong dan menjaga kebersihan lingkungan. Selain itu, perlu adanya pendampingan kepada masyarakat dari pihak-pihak terkait baik pemerintah maupun swasta untuk memupuk kesadaran masyarakat dalam mempertahankan kelestarian lingkungan.

\section{UCAPAN TERIMA KASIH}

Ucapan terima kasih kami sampaikan kepada pendamping Program Keluarga Harapan Kecamatan Woyla dan juga Keuchik Gampong Rantau Panyang Kecamatan Woyla Kabupaten Aceh Barat yang telah memberikan izin untuk kegiatan pengabdian masyarakat ini. 


\section{DAFTAR PUSTAKA}

Agomo CO, Oyibo WA, 2013. Factors

Associated With Risk of Malaria Infection Among Pregnant Women in Lagos, Nigeria. Infect Disease Poverty 2013;2(1):19.

Amanah, S, 2007. Makna

Penyuluhan dan Transformasi Perilaku Manusia. Jurnal Penyuluhan; 3(1),5, https://doi.org/10.25015/penyul uhan.v3i1.2152)

Amegah AK, Damptey OK, Sarpong GA, Duah E, Vervoom DJ, Jaakkola JJ, 2013. Malaria Infection, Poor Nutrition and Indoor Air Pollution Mediate Sosioeconomic differences in Adverse Pregnancy Outcomes in Cape Coast, Ghana. PLoS One 2013;8(7) e69181.

Budiasih, KS, 2011. Pemanfaatan Beberapa Tanaman yang Berpotensi Sebagai Bahan Anti Nyamuk. Artikel. Yogyakarta: Pendidikan Kimia Fakultas MIPA UNY.

Chan DM, 2015. WHO Global Malaria Programme, World Malaria Report. Geneva.

Dinas Kesehatan Provinsi Aceh, 2010. Profil Kesehatan Provinsi Aceh. Aceh.

Harijanto PN., 2000. Gejala Klinik Malaria. Dalam: Harijanto PN (editor) Malaria, Epidemiologi, Patogenesis, Manifestasi Klinis dan Penanganan. Jakarta: EGC, Hal 151-55.

Harijanto PN, Langi J, Richie TL.,
2000. Pathogenesis Malaria Berat. Dalam: Harijanto PN (editor). Malaria, Epidemiologi, Patogenesis, Manifestasi Klinis dan Penanganan. Jakarta: EGC, Hal 118-26.

Purwaningsih, S, 2000. Diagnosis Malaria. Dalam: Harijanto PN (editor). Malaria, Epidemiologi, Patogenesis, Manifestasi Klinis dan Penanganan. Jakarta: EGC, Hal:185-92.

Riskesdas, 2013. Badan Penelitian dan Pengembangan Kesehatan. Jakarta: Kementerian Kesehatan Republik Indonesia.

Riskesdas, 2018. Badan Penelitian dan Pengembangan Kesehatan. Jakarta: Kementerian Kesehatan Republik Indonesia.

Suwonkerd W, Ritthison W, Ngo CT, Krajana T, Bangs MJ, Chareonviriyaphap T., 2013. Anopheles Mosquitoes - New Insight Into Malaria Vectors. Vector Biology and Malaria Transmission in Southeast Asia. Rijeka: In Tech;2013.

Triana D, Rosana E, Anggraini R., 2017. Pengetahuan dan Sikap Terhadap Perilaku dalam Penanggulangan Malaria di Kelurahan Sukarami Kota Bengkulu. Unnes Journal of Public Health, 6(2):107-112.

WHO, 2000. WHO Expert Committee on Malaria, Twentieth Report, World Health Organization Technical Report 
Series 892, Geneva.

Winardi E, 2004. Faktor-Faktor Yang

Berhubungan Dengan Kejadian

Malaria di Kecamatan Selebar

Kota Bengkulu. Tesis. Universitas

Indonesia. 